\title{
Optical and hygroscopic properties of black carbon influenced by particle microphysics at the top of the anthropogenically polluted boundary layer
}

\author{
Shuo Ding ${ }^{1}$, Dantong Liu ${ }^{1}$, Kang Hu${ }^{1}$, Delong Zhao ${ }^{2,3}$, Ping Tian ${ }^{2,3}$, Fei Wang ${ }^{2}$, Ruijie $\mathrm{Li}^{2}$, Yichen Chen ${ }^{2} \mathrm{Hui} \mathrm{He}^{2}$, \\ Mengyu Huang ${ }^{2}$, and Deping Ding ${ }^{2}$ \\ ${ }^{1}$ Department of Atmospheric Sciences, School of Earth Sciences, Zhejiang University, Hangzhou, China \\ ${ }^{2}$ Beijing Weather Modification Office, Beijing, China \\ ${ }^{3}$ Beijing Key Laboratory of Cloud, Precipitation and Atmospheric Water Resources, Beijing, China
}

Correspondence: Dantong Liu (dantongliu@zju.edu.cn) and Deping Ding (zytddp@vip.sina.com)

Received: 24 July 2020 - Discussion started: 17 August 2020

Revised: 10 November 2020 - Accepted: 6 December 2020 - Published: 18 January 2021

\begin{abstract}
Aerosols at the top of the planetary boundary layer (PBL) could modify its atmospheric dynamics by redistributing the solar radiation and start to be activated to form low-level cloud at this layer. Black carbon (BC), as an aerosol component efficiently absorbing solar radiation, can introduce heating and positive radiative effects at this sensitive layer, especially in the polluted PBL over the continent. This study presents continuous measurements of detailed $\mathrm{BC}$ properties at a mountain site located at the top of the polluted PBL over the North China Plain, during seasons ( 3 and 4 weeks of data during winter and summer, respectively) with contrasting emission structure and meteorology. The pollution level was persistently influenced by local surface anthropogenic emission on a daily basis through daytime convective mixing, but the concentration was also enhanced or diluted depending on air mass direction, defined as a neutral, polluted and diluted PBL, respectively. Winter was observed to have a higher BC mass fraction (4\%-8\%) than summer $(2 \%-7 \%)$. By resolving the detailed particle size-resolved mixing state of $\mathrm{BC}$ in optical and hygroscopic models, we found an enhanced $\mathrm{BC}$ mass absorption cross section $\left(\mathrm{MAC}_{\mathrm{BC}}\right.$ ) for the polluted PBL (up to $13 \mathrm{~m}^{2} \mathrm{~g}^{-1}$ at $\lambda=550 \mathrm{~nm}$ ), which was $5 \%$ higher during summer than winter due to a smaller $\mathrm{BC}$ core size. The higher $\mathrm{BC}$ mass fraction in winter corresponded to a lower single-scattering albedo by $0.03-0.09$ than summer, especially the lowest for the diluted winter PBL $(0.86 \pm 0.02)$. The water supersaturation (SS) required to activate half the number of $\mathrm{BC}$ de-
\end{abstract}

creased from $0.21 \% \pm 0.08 \%$ to $0.1 \% \pm 0.03 \%$ for the winter diluted and polluted PBL and from $0.22 \% \pm 0.06 \%$ to $0.17 \% \pm 0.05 \%$ for summer. Notably, at the top of the anthropogenically polluted PBL in both seasons, the enlarged BC with enhanced absorption capacity could also be efficiently droplet activated; e.g. winter (summer) BC with an MAC of $9.84 \pm 1.2(10.7 \pm 1) \mathrm{m}^{2} \mathrm{~g}^{-1}$ could be half activated at $\mathrm{SS}=0.13 \% \pm 0.06 \%(0.18 \% \pm 0.05 \%)$. This $\mathrm{BC}$ at the top of the PBL can more directly interact with the free troposphere and be transported to a wider region, exerting important direct and indirect radiative impacts.

\section{Introduction}

Black carbon (BC) aerosol is strongly shortwave absorbing, wielding an important climate warming impact on the regional and global scales (Bond et al., 2013; Bond and Bergstrom, 2006). The emission of $\mathrm{BC}$ has large regional heterogeneity with a higher impact over polluted regions (Ramanathan and Carmichael, 2008). The impacts due to BC heating are importantly determined by its vertical distribution in the atmospheric column, which could lead to a more stable or convective planetary boundary layer (PBL) (Ding et al., 2016; Koch and Del Genio, 2010); e.g. an enhanced heating at a higher level will depress the development of the layer below (Chung et al., 2002; Ramanathan et al., 2005; Hansen et al., 2005), while the heating can promote the con- 
vection above (Mcfarquhar and Wang, 2006; Rudich et al., 2003); e.g. BC was found to account for $43 \%$ of the total aerosol radiative forcing at the atmosphere in South Asia due to heating (Raju et al., 2020). Therefore, the properties of $\mathrm{BC}$ at the top of the PBL are important, which may result in contrasting impacts in perturbing atmospheric dynamics. In addition, surface emissions could serve regular cloud condensation nuclei $(\mathrm{CCN})$ on a daily basis through daytime convective mixing in the PBL (Bretherton and Wyant, 1997; Wood and Bretherton, 2004). Aerosols can be uplifted to the top of the PBL and subsequently activated to incorporate into clouds. However, the way of $\mathrm{BC}$ from surface sources to be activated, after the PBL processing during vertical transport, is yet to be explicitly understood.

Ground measurements of BC have been intensively conducted over the polluted North China Plain (NCP) region in the last decades (Han et al., 2009; Cheng et al., 2011; Ji et al., 2018; Liu et al., 2019a); e.g. the seasonal variation of elemental carbon in urban Beijing during 2005/06 and 2012/13 (Han et al., 2009; Ji et al., 2018), the size-resolved mixing state of $\mathrm{BC}$ and the aging mechanism at a suburban site in the NCP (Cheng et al., 2011), and the contrasting physical properties in urban Beijing between winter and summer (Liu et al., 2019a) were investigated in these studies, but these results were not able to represent the $\mathrm{BC}$ properties at the top of the PBL. Additionally, recently conducted series of aircraft measurements provided comprehensive information about vertical distributions of $\mathrm{BC}$ over this region (Zhao et al., 2019; Ding et al., 2019a), but the manner of the aircraft measurement could not capture the variation of $\mathrm{BC}$ at a certain level at sufficient time resolution. The nature of the diurnal pattern of the PBL means that not only is the surface concentration of pollutants influenced by the daily evolution of the PBL, but that the pollutants at the top of the PBL will also have diurnal variation which needs stable measurements to be characterized. This is particularly the case if the top of the PBL was continuously influenced by surface emissions. However, such information is lacking at the top of the PBL over the polluted NCP region, and many models still rely on surface measurements to estimate the conditions at higher levels (Guleria et al., 2014; Srivastava et al., 2012a).

Microphysical properties of BC importantly determine its optical and hygroscopic properties. For example, the presence of coatings associated with refractory $\mathrm{BC}(\mathrm{rBC})$ may enhance its absorbing capacity (Liu et al., 2017) and also enhance its hygroscopicity (Liu et al., 2013) and particle size, thereby modifying the potential to be droplet activated (Chuang et al., 2002; Panicker et al., 2016; Ding et al., 2019b). This study for the first time characterizes the detailed BC microphysics at a mountain site located at the top of the PBL, influenced by surface emission on a daily basis over the NCP region. We have conducted the experiments with intensive measurements lasting for 1 month for each of the representative seasons. We investigated the optical and hygroscopic properties of $\mathrm{BC}$ at this level, as influenced by microphysical properties. Such information will help to constrain the impacts of BC in influencing the PBL dynamics and low-level cloud formation over this anthropogenically polluted region.

\section{Site description, meteorology, cluster classification}

Experiments in this study were performed in winter (February-March) and summer (June-July) of 2019 at a mountain site $\left(115.78^{\circ} \mathrm{E}, 40.52^{\circ} \mathrm{N} ; 1344 \mathrm{~m}\right)$, located north of Taihang ridge to the northwest of central Beijing, shown in Fig. 1a. The site is away from any local primary emissions, but the only sources of pollutants are contributed by lowerlevel surface emissions and regional transport (the follow-up discussions).

Backward trajectories at the site are analysed using the HYSPLIT 4.0 model (Draxler and Hess, 1998) for every $6 \mathrm{~h}$ during the experimental period. The meteorological field uses the $1^{\circ} \times 1^{\circ}, 3$-hourly GDAS1 reanalysis product, and trajectories back to $48 \mathrm{~h}$ are calculated. The backward trajectories are used for further cluster analysis to group the backward trajectories with a similar transport pathway, whereby the homogeneity of trajectories is maximized in each cluster; meanwhile, the heterogeneity among different clusters is maximized (Makra et al., 2011). This is achieved by analysing the spatial variance of each trajectory and the total variance in each pre-defined cluster. The iteration next simultaneously calculates and assigns the trajectories to the eventually merged clusters. This analysis has been widely used to identify the main transport pathways of air mass (Markou and Kassomenos, 2010; Philipp, 2009; Jorba et al., 2004; Grivas et al., 2008) and is performed using the built-in module in the HYSPLIT model software.

\section{Instrumentation}

All aerosol measurements were performed behind a $\mathrm{PM}_{2.5}$ impactor (BGI SCC1.829) and were dried by a Nafion tube prior to the sampling of the instruments. BC was measured by a single-particle soot photometer (SP2) (DMT Inc. USA). This instrument uses a laser-induced technique to incandesce BC-containing particles (Schwarz et al., 2006; Liu et al., 2010). The measured incandescence signal of an individual $\mathrm{BC}$ particle can be converted to a refractory $\mathrm{BC}(\mathrm{rBC})$ mass, which was calibrated using the Aquadag ${ }^{\circledR} \mathrm{BC}$ particle standard (Acheson Inc.), and a factor of 0.75 was applied to correct for the ambient $\mathrm{rBC}$ mass (Laborde et al., 2012). The core size $\left(D_{\mathrm{c}}\right)$ of $\mathrm{BC}$ is calculated from the measured $\mathrm{rBC}$ mass by assuming a material density of $\mathrm{BC}$ of $1.8 \mathrm{~g} \mathrm{~cm}^{-3}$ (Bond and Bergstrom, 2006). The scattering cross section of $\mathrm{BC}$ is derived by the leading edge only (LEO) method (Gao et al., 2007) on the measured scattering signal of an individual BC particle. The entire particle size of a BC-containing particle $\left(D_{\mathrm{p}}\right)$ including coatings is determined by matching 

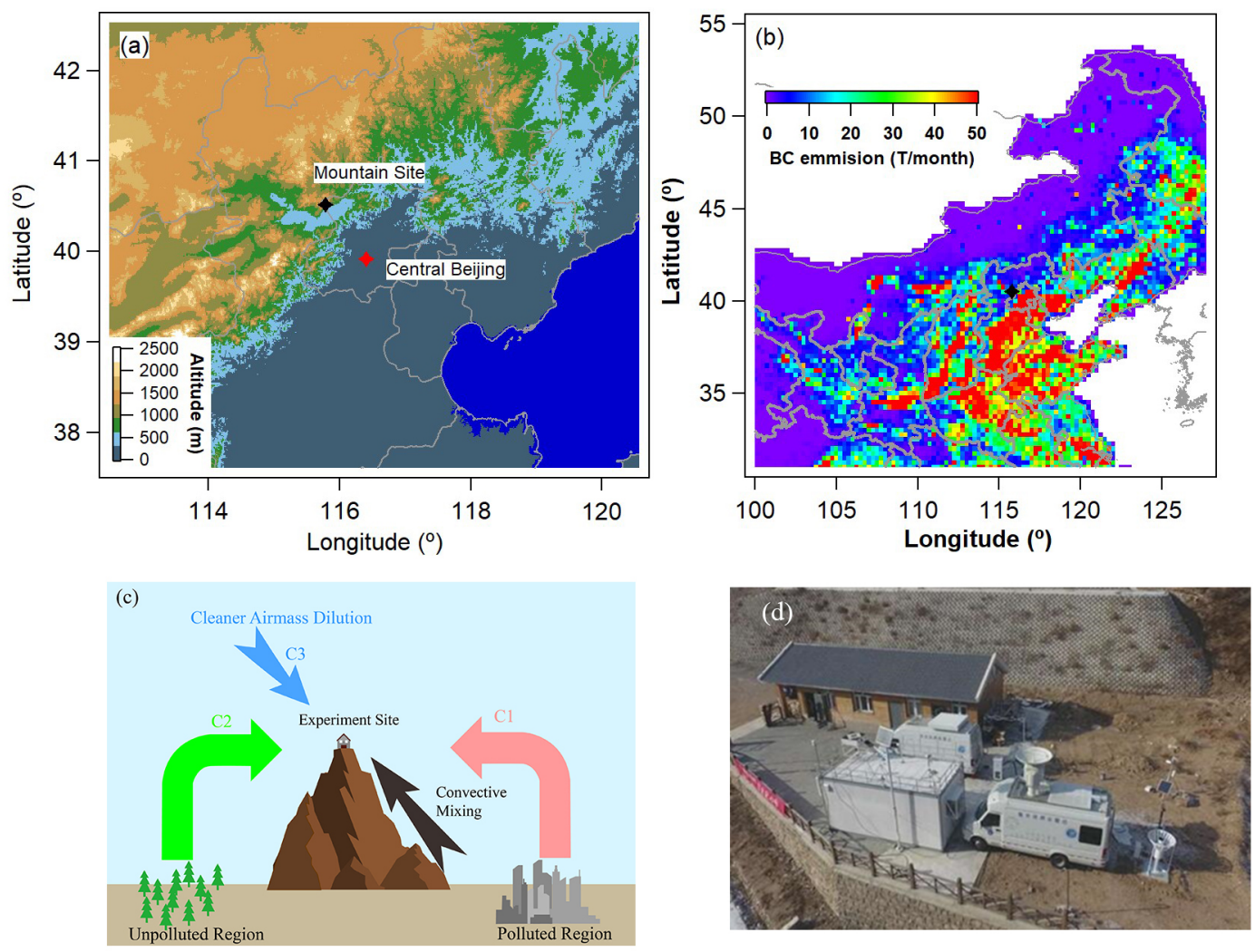

Figure 1. Experimental site descriptions. (a) The location of the experimental site and central Being, marked with black and red stars, respectively, where the colour bar denotes the terrain height and blue denotes the sea. (b) The monthly BC emission inventory in China (Li et al., 2017). (c) Schematic illustration for different types of PBLs defined in this study. (d) Photo of the mountain station.

the measured scattering cross section with the modelled one based on a core-shell assumption using a Mie lookup table (Liu et al., 2014; Taylor et al., 2015). This assumption is mostly valid for BC with thick coatings (Liu et al., 2017) but does not consider the scenario in which BC may be attached to dust particles (Srivastava et al., 2018), given that no dust event was observed in this study. The bulk coating thickness $\left(D_{\mathrm{p}} / D_{\mathrm{c}}\right)$ in a given time window is calculated as the cubic root of the total volume of $\mathrm{BC}$-containing particles weighted by the total volume of rBC (Liu et al., 2014):

$\frac{D_{\mathrm{p}}}{D_{\mathrm{c}}}=\sqrt[3]{\frac{\sum_{i} D_{\mathrm{p}, i}^{3}}{\sum_{i} D_{\mathrm{c}, i}^{3}}}$,

where $D_{\mathrm{p}, i}$ and $D_{\mathrm{c}, i}$ are the diameters for the $i$ th single particle, respectively. The count (or mass) median diameter (CMD or MMD) is derived from a number (or mass) size distribution, below and above which size the number (or mass) concentration is equal. The modelled mass absorption cross section (MAC) of an individual BC-containing particle is calculated by applying Mie theory (Bohren, 1998) with a coreshell mixing state assumption. The bulk MAC for a given time window can then be determined by the total MAC of each $\mathrm{BC}$ particle divided by the total $\mathrm{rBC}$ mass, expressed as

$\mathrm{MAC}=\frac{\sum_{i} \mathrm{MAC}_{i} \cdot m_{\mathrm{rBC}, i}}{\sum_{i} m_{\mathrm{rBC}, i}}$,

where $\mathrm{MAC}_{i}$ and $m_{\mathrm{rBC}, i}$ are the MAC and $\mathrm{rBC}$ mass for each particle, respectively. An example to calculate the MAC from single-particle information is shown in Fig. 5f. The absorption coefficient $k_{\mathrm{abs}}$ (in $\mathrm{Mm}^{-1}$ ) is calculated as the MAC $\left(\mathrm{m}^{2} \mathrm{~g}^{-1}\right)$ multiplying the $\mathrm{rBC}$ mass concentration $\left(\mu \mathrm{g} \mathrm{m}^{-3}\right)$ in each size bin and then integrated throughout the size distribution:

$k_{\mathrm{abs}}=\sum_{i} \operatorname{MAC}\left(D_{\mathrm{p}, i}, D_{\mathrm{c}, i}\right) m\left(\log D_{\mathrm{c}, i}\right) \Delta \log D_{\mathrm{c}, i}$,

where $m\left(\log D_{\mathrm{c}, i}\right)$ is the $\mathrm{BC}$ mass concentration at each $D_{\mathrm{c}}$ bin.

The volume ratio between coating and $\mathrm{rBC}$ could be obtained from $D_{\mathrm{c}}$ and $D_{\mathrm{p}}$ of individual BC:

$\frac{\varepsilon_{\text {coating }}}{\varepsilon_{\mathrm{rBC}}}=\left(\frac{D_{\mathrm{p}}}{D_{\mathrm{c}}}\right)^{3}-1$,

where $\varepsilon_{\text {coating }}$ and $\varepsilon_{\mathrm{rBC}}$ are the volume fraction within a $\mathrm{BC}$ particle. The hygroscopicity parameter of $\mathrm{BC}\left(\kappa_{\mathrm{BCc}}\right)$ could 

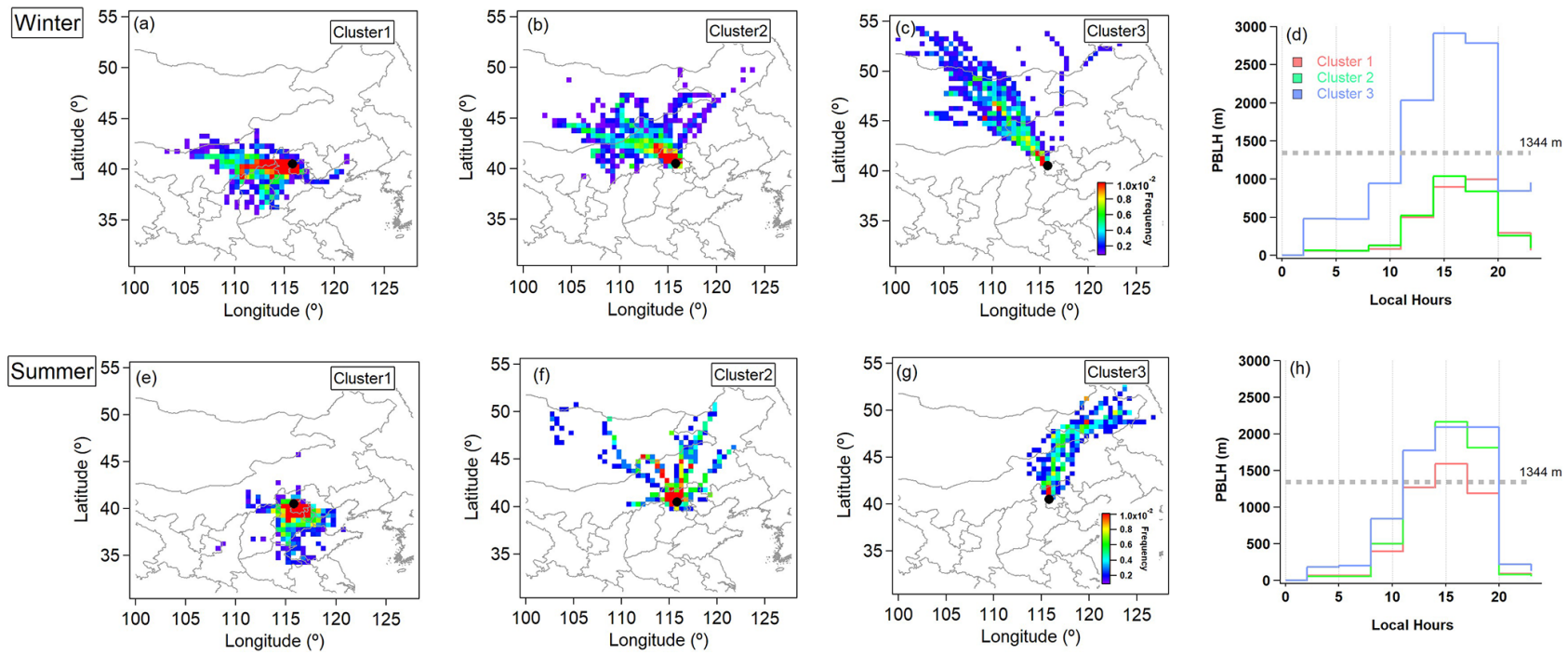

Figure 2. The clustered backward trajectories from the HYSPLIT model in both seasons: (a-c) for winter and (e-g) for summer, coloured by occurrence frequency in each geographic grid. Panels (d) and (h) are the diurnal variation of the height of the PBL for the three clusters in both seasons, with the dashed line denoting the mountain site altitude.

be calculated with known $\kappa_{\text {coating }}$ and $\kappa_{\mathrm{rBC}}=0$, based on the Zdanovskii-Stokes-Robinson (ZSR) rule (Stokes and Robinson, 1966), expressed as

$\kappa_{\mathrm{BCc}}=\varepsilon_{\text {coating }} \cdot \kappa_{\text {coating }}$.

In this study, the main focus is the coating abundance distribution across all $\mathrm{BC}$ size distributions, but the variation of coating composition is of less importance; thus, a constant $\kappa_{\text {coating }}=0.3$ is used to represent a typical environment containing aged aerosols (Pringle et al., 2010). An example to calculate $\kappa_{\mathrm{rBC}}$ from single-particle information is shown in Fig. $5 \mathrm{~g}$.

Total aerosol size distribution was measured by a Scanning Mobility Particle Sizer (SMPS, TSI Inc., model 3936) at mobility diameter $15-700 \mathrm{~nm}$. The total particle mass below diameter $1 \mu \mathrm{m}\left(\mathrm{PM}_{1}\right)$ is derived from the SMPS size distribution by assuming a mean particle density of $1.45 \mathrm{~g} \mathrm{~cm}^{-3}$ (Liu et al., 2015; Cross et al., 2007). The scattering cross section $\sigma_{\mathrm{sc}}\left(\mu \mathrm{m}^{2}\right)$ of a particle at all sizes is calculated by applying Mie calculation assuming a refractive index (RI) of $1.48+0 \mathrm{i}$ (Liu et al., 2009) (a positive imaginary RI considering the $\mathrm{BC}$ mass fraction is tested to have a minor influence on total scattering within $3 \%$ ), thereby calculating the scattering coefficient $k_{\text {sca }}$ (in $\mathrm{M} \mathrm{m}^{-1}$ ) of all aerosols:

$k_{\mathrm{sca}}=\sum_{i} \sigma_{\mathrm{sc}}\left(D_{i}\right) n\left(\log D_{i}\right) \Delta \log D_{i}$,

where $n\left(\log D_{i}\right)$ represents the particle number concentration at the $i$ th size bin. Single-scattering albedo (SSA) is derived as the quotient of scattering coefficient $\left(k_{\mathrm{sca}}\right)$ divided by extinction coefficient $\left(k_{\mathrm{abs}}+k_{\mathrm{sca}}\right)$.

\section{Results and discussion}

\subsection{Classification of the PBL}

Clustered air masses for both seasons are shown in Fig. 2, and three clusters are classified for each season. For both seasons, cluster $1(\mathrm{C} 1)$ represents the air masses from the most intensive anthropogenically influenced regions according to the $\mathrm{BC}$ emission inventory (Fig. 1b). The seasonal difference is that the winter pollution was transported from the west over Shanxi and Hebei provinces and was southerly in summer mainly from the North China Plain over Hebei province. Cluster 2 (C2) passed over similar regions in both seasons from the cleaner north. Cluster 3 (C3) had a longer transport than both other clusters, from northwest and northeast in winter and summer, respectively. The diurnal variations of PBL height (PBLH) corresponding to periods of each cluster are shown in Fig. $2 \mathrm{~d}$ and $\mathrm{h}$, with a pronounced diurnal pattern. Apart from C3, winter had a lower PBLH than summer; i.e. the mountain site was slightly above or below the well-developed PBL top in winter and summer, respectively. The consistent diurnal variation of the PBL means the mountain site was persistently influenced by the surface sources through daytime convective mixing, when pollutants were transported in the polluted PBL. However, the actual concentration will depend on whether the site had contributions by additional sources or dilution (Fig. 1c).

Figure 3 shows the temporal evolution of $\mathrm{BC}$ mass and PM for both seasons classified by air mass clusters, with panels $\mathrm{g}$ to 1 showing the frequency under each cluster. Figure 4 shows their diurnal variations. For all experimental periods, the concentration level of $\mathrm{BC}$ mass was gener- 

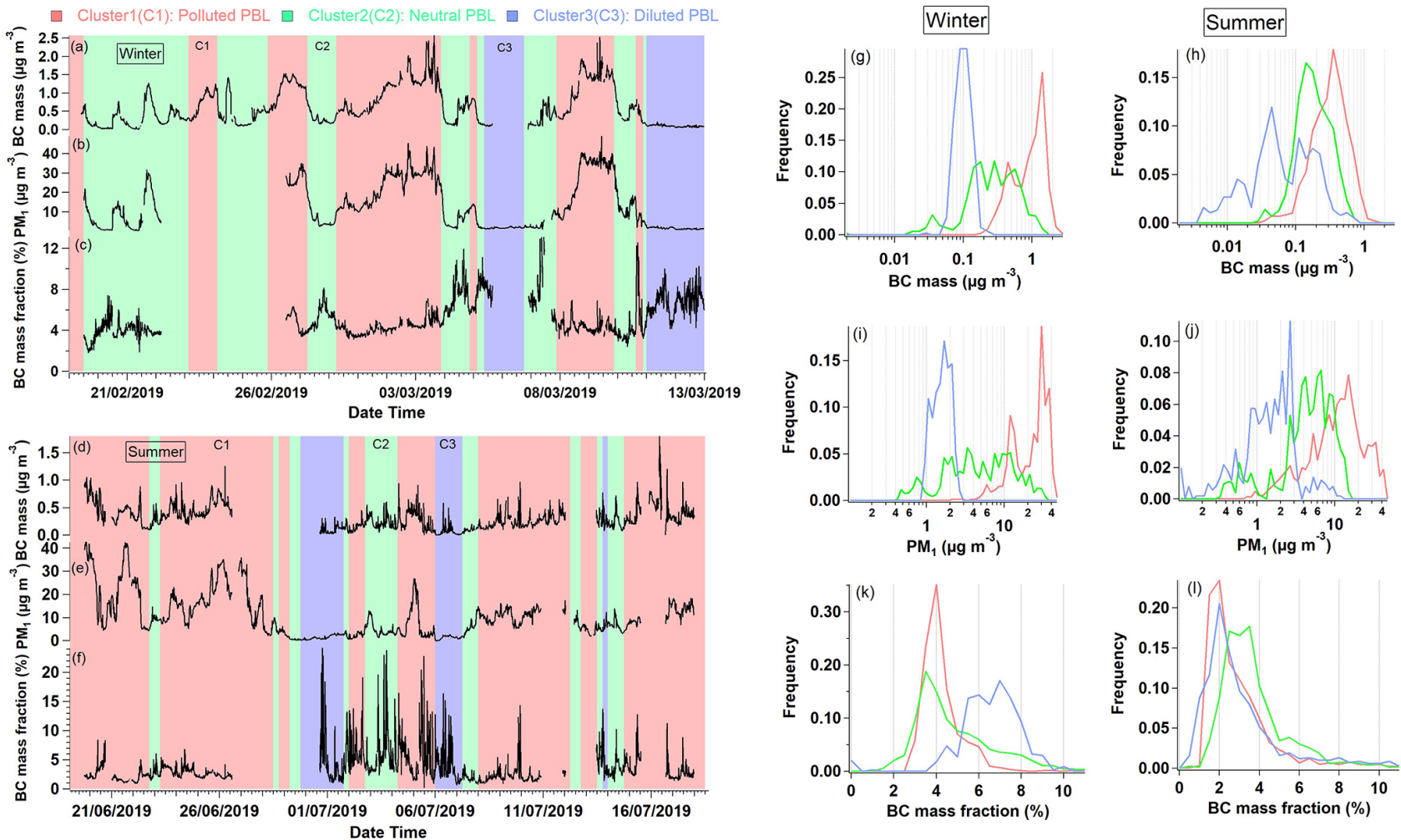

Figure 3. Time series of BC mass (a, d), $\mathrm{PM}_{1}$ derived from the SMPS size distribution (b, e), and BC mass fraction (c, f) at both seasons, shaded by the periods in the identified three clusters, by red, green and blue corresponding to cluster 1 (C1), cluster 2 (C2), and cluster 3 (C3), respectively. Frequency histograms of BC mass $(\mathbf{g}, \mathbf{h}), \mathrm{PM}_{1}(\mathbf{i}, \mathbf{j})$, and BC mass fraction $(\mathbf{k}, \mathbf{l})$ for each cluster in both seasons.

ally positively correlated with the PM mass, both indicating the pollution levels. Among the three clusters, $\mathrm{C} 2$ had the medium mass concentration, with over $85 \%$ frequency of the air masses contributed by local regions $\left( \pm 1^{\circ}\right.$ around the measurement site), and additional air masses were from the cleaner northerly direction, similar for both seasons (Fig. 2). It is likely that this cluster was mainly contributed by local emission and occasionally diluted to some extent by the air mass from a less polluted region. Here this cluster is defined as the "neutral PBL" to distinguish it from the other two clusters. In winter $\mathrm{C} 2$ showed clear diurnal variation of $\mathrm{BC}$ and $\mathrm{PM}_{1}$ concentrations, with significant enhancement in the daytime (Fig. 4b and e) with a fully developed PBL (Fig. 2d), with the diurnal pattern consistent with a previous study conducted in the Indian Himalayan foothills (Srivastava et al., $2012 b$ ). This diurnal pattern on the mountain was in contrast with the usual surface measurement, when the daytime PBL development could dilute the concentration (Liu et al., 2019a; Han et al., 2009). This opposite trend on the mountain site was consistent with the fully developed PBLH at 12:0016:00 (Fig. 2d) when the top of the PBL reached the mountain site at this time, and pollutants were transported through convective mixing from the surface sources (Fig. 1c). At midnight, the nocturnal depressed PBL trapped the surface pollution towards the mountain, and the subsiding cleaner air in the free troposphere may have diluted the concentration of pollutants on the mountain site (Sullivan et al., 1998; Bennett et al., 2010). The enhanced concentration from midday in summer was also observed (on the mean, Fig. 4a) but was not as pronounced as in winter, probably due to some wet removal during the daytime vertical transport from the surface, given the high relative humidity (RH) in the summer (Fig. S1 in the Supplement).

Consistent with the combined back-trajectory and emission analysis above, $\mathrm{C} 1$ had for both seasons the highest BC $\left(1.0 \pm 0.5\right.$ and $0.4 \pm 0.2 \mu \mathrm{g} \mathrm{m}^{-3}$ for winter and summer, respectively) and the highest PM mass (23.8 \pm 10.3 and $13.4 \pm 9.5 \mu \mathrm{g} \mathrm{m}^{-3}$ ). Compared to $\mathrm{C} 1$, for $\mathrm{C} 2$, the concentration of $\mathrm{BC}$ mass was enhanced by a factor of 2.8 (1.7) higher than that in $\mathrm{C} 2$ for winter (summer), with winter having a mass concentration frequently exceeding $1 \mu \mathrm{g} \mathrm{m} \mathrm{m}^{-3}$. C1 clearly shows the diminished diurnal variation compared to the neutral PBL of $\mathrm{C} 2$, but all increased throughout the day and night (Fig. 4a and d), particularly for winter. This is because besides the persistent influence of daytime convective mixing as the neutral cluster in $\mathrm{C} 2, \mathrm{C} 1$ had an additional contribution from wider polluted regions, here defined as "polluted PBL" (Fig. 1c). This contribution by regional transport was not related to a diurnal pattern. The lower concentration 

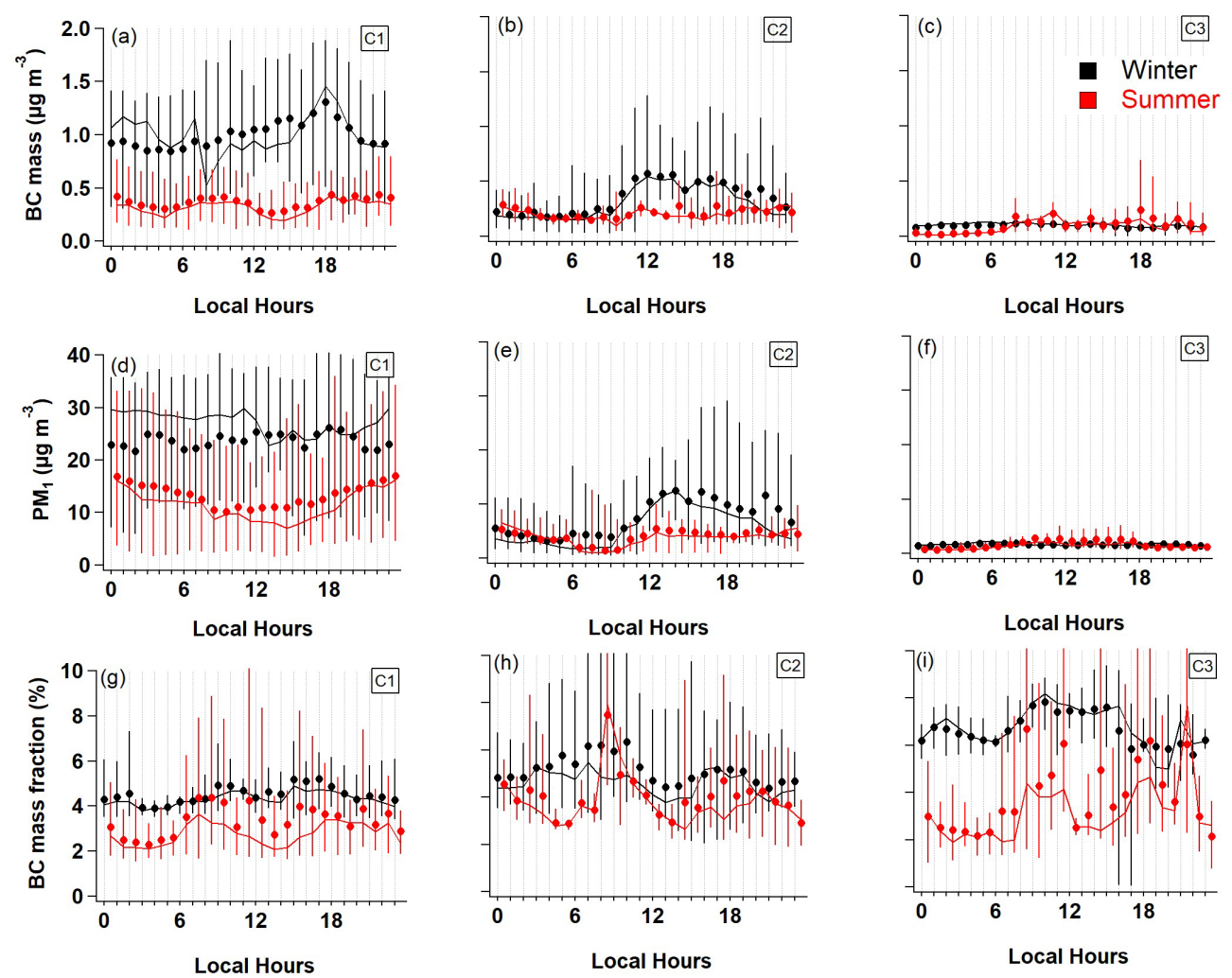

Figure 4. Diurnal variation of $\mathrm{BC}$ mass $(\mathbf{a}-\mathbf{c}), \mathrm{PM}_{1}(\mathbf{d}-\mathbf{f})$ and $\mathrm{BC}$ mass fraction $(\mathbf{g}-\mathbf{i})$ for the three PBL types in both seasons, where black and red denote the winter and summer, respectively. The solid circles, lines and whiskers denote the mean, median, and 25 th and 75 th percentiles, respectively.

in the summer mountain may also result from the lower surface emission in the season.

C3 had the lowest pollution level among all air mass clusters, with a lower $\mathrm{BC}\left(0.09 \pm 0.03 \mu \mathrm{g} \mathrm{m}^{-3}\right)$ and $\mathrm{PM}_{1}$ mass $\left(1.8 \pm 0.4 \mu \mathrm{g} \mathrm{m}^{-3}\right)$ than $\mathrm{C} 2$ by a factor of $2-4$, within a similar range of a previous study in the western and central Himalayas (Nair et al., 2013). C3 represented the air masses from regions with low emissions (Fig. 1b). In addition, the faster transport (shown as the longest path for back trajectories among clusters, Fig. 2c) and the highest PBLH (Fig. 2d) in $\mathrm{C} 3$ could efficiently dilute the pollution in the PBL, here termed "diluted PBL". Compared to C2, C3 can efficiently disperse and reduce the pollutants being vertically transported to the mountain site from the surface, thus with no apparent diurnal pattern of pollution concentrations either (Fig. 4c).

$\mathrm{BC}$ mass fraction in $\mathrm{PM}_{1}$ was overall higher in winter than summer, on average at $5.1 \% \pm 1.7 \%$ and $3.6 \% \pm 2.3 \%$, respectively, with both seasons showing a frequency distribution skewed to higher values up to $10 \%$ (Fig. $3 \mathrm{k}$ and 1). Note that in summer the BC mass fraction among clusters had no discernible differences, with only $\mathrm{C} 2$ shown to be slightly higher. The overall higher $\mathrm{BC}$ mass fraction in winter may result from the seasonal variation in emission structure that the additional primary emissions from heating activities may have introduced more fractions of BC (Chow et al., 2011; Liu et al., 2018). However, the lowered BC mass fraction for the polluted PBL in winter (with a significant reduction for fraction $>7 \%$ ) may result from the enhanced secondary formation in a polluted environment (Volkamer et al., 2006; Hallquist et al., 2009). The comparable BC mass fraction between $\mathrm{C} 1$ and $\mathrm{C} 3$ in summer (but all lower than neutral PBL) may result from the dominant process of enhanced secondary formation (reducing $\mathrm{PM}_{1}$ ) and particle scavenging (reducing BC) for polluted and diluted PBL, respectively. There was a notably higher $\mathrm{BC}$ mass fraction at $6.7 \% \pm 1.5 \%$ for the diluted PBL in winter, suggesting a much reduced secondary aerosol in a less polluted environment, and the removal process of $\mathrm{BC}$ had been less efficient than other substances (Koch and Del Genio, 2010).

\subsection{Particle microphysics of $\mathrm{BC}$}

BC core size showed no variation among all PBL types in both seasons. The mass (count) median diameter of the $\mathrm{BC}$ core is $203 \pm 12 \mathrm{~nm}(106 \pm 7 \mathrm{~nm})$ and $167 \pm 11 \mathrm{~nm}$ $(85 \pm 5 \mathrm{~nm})$ for winter and summer, respectively. The BC core size could be used to discern emission sources, such as $\mathrm{BC}$ from solid fuel burning that tended to have a larger MMD 

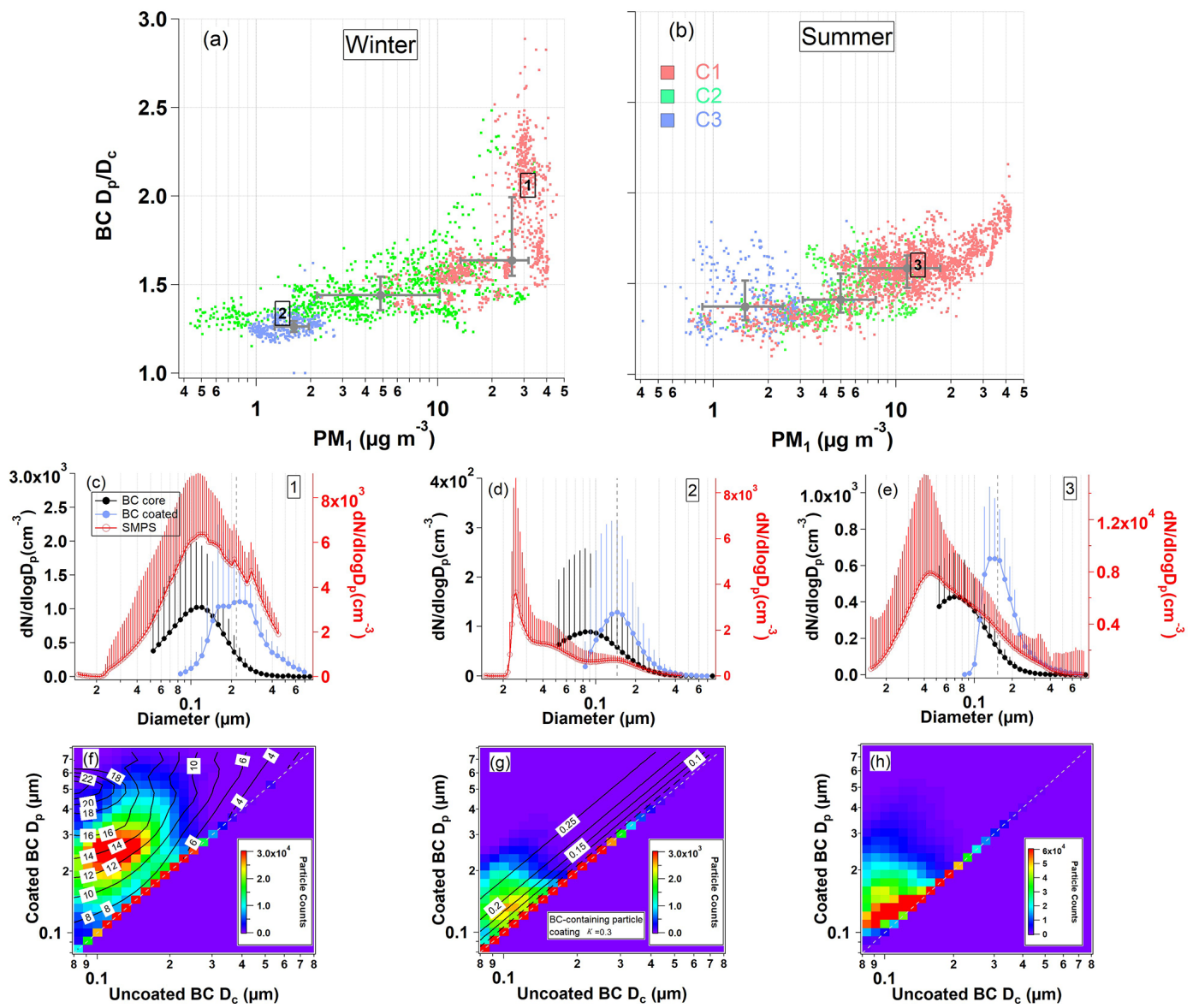

Figure 5. Size-resolved mixing state of BC. The bulk relative coating thickness $\left(D_{\mathrm{p}} / D_{\mathrm{c}}\right)$ as a function of $\mathrm{PM}_{1}$ in winter (a) and summer (b) for the three PBL types, with solid circles and whiskers denoting the median and 25th and 75th percentiles, respectively. Three typical periods, marked as 1-3 in (a) and (b), are extracted for size distribution analysis. Panels (c)-(e) are the corresponding number size distribution of all particles and uncoated and coated BC for periods 1-3, respectively. The bottom panels are coated BC diameter as a function of uncoated BC diameter, coloured by the number density of a single particle, where (f) and (g) are mapped with contour lines numbered by the $\mathrm{MAC}$ and $\kappa_{\mathrm{BCc}}$, respectively.

compared to those from traffic sources (Liu et al., 2014). The larger MMD in winter than summer was consistent with previous observation over this region (Ding et al., 2019a; Hu et al., 2020), which may indicate additional sources from residential solid fuel burning for heating in the cold season.

The coatings relative to $\mathrm{BC}$, as reflected by $D_{\mathrm{p}} / D_{\mathrm{c}}$, were positively correlated with the pollution level of the PBL (represented by $\mathrm{PM}_{1}$ mass loading) in winter (Fig. 5a) and in summer from a neutral to polluted PBL (Fig. 5b). The polluted PBL in winter had the highest $D_{\mathrm{p}} / D_{\mathrm{c}}(1.76 \pm 0.3)$, in line with the most polluted condition. For both neutral and diluted PBLs, winter had higher BC coatings than summer. Apart from some periods in summer, the diluted PBL occasionally showed higher $D_{\mathrm{p}} / D_{\mathrm{c}}$ up to 1.8 , comparable with the high end of that for the polluted PBL.

The warmer temperature in summer may have caused a more likely tendency for some semi-volatile particle species to evaporate, thereby reducing coatings on $\mathrm{BC}$ in winter even at the same pollution level, which is consistent with previous ground studies over this region (Liu et al., 2019a). The highest coatings were associated with the most polluted condition, implying that the regional transport of air mass from a wider polluted region may have advected both primary emissions and gas precursors when some gas-partitioning processes may have occurred on BC during transport and caused the high coatings. In a clean environment, summer showed remarkably higher coatings than winter, which may result from more intense solar radiation received at the mountain site in summer, where photochemical reactions may have caused significant formation of secondary particulate matter (Xu et al., 2017; Bao et al., 2018; Liu et al., 2019b).

The detailed size distributions of uncoated and coated BC are shown in Fig. 5c and e. Here three typical examples are chosen to represent the polluted and diluted PBLs in winter (case 1 and case 2) and the polluted PBL in summer (case 3 ). Comparing between case 1 and case 2, it showed that 
the polluted period had caused increased size for all particles from peak diameter $(d)$ less than $d=30 \mathrm{~nm}$ to the accumulation mode of $d=120 \mathrm{~nm}$. Coated BC diameter peaked from 150 to $220 \mathrm{~nm}$. This means the condensation process had occurred on all particles and enlarged their sizes, including BC. The coated $\mathrm{BC}$ in the most polluted PBL significantly extended its coated size up to $d=400-700 \mathrm{~nm}$. Note that for the clean PBL in winter, the coated $\mathrm{BC}$ was populated at $d=150 \mathrm{~nm}$, leading to a higher BC number fraction of $22 \%$ at this size. For the polluted PBL in summer, the peaking diameter of all particles $(d=450 \mathrm{~nm})$ was lower than winter, and coated BC also peaked at a smaller size $(d=153 \mathrm{~nm})$. Figure $\mathrm{S} 3$ shows almost consistent coated $\mathrm{BC}$ sizes in summer $(120-130 \mathrm{~nm})$, which was smaller than winter because of the smaller core size (though with a higher $D_{\mathrm{p}} / D_{\mathrm{c}}$ ).

Detailed core-size-resolved mixing states, expressed in a space of coated vs. uncoated BC diameter, are shown in Fig. $5 \mathrm{f}-\mathrm{h}$, corresponding to the three cases above. $D_{\mathrm{p}}=D_{\mathrm{c}}$ indicates no coatings on $\mathrm{BC}$ and coating increases when $D_{\mathrm{p}}$ is larger than $D_{\mathrm{c}}$. For the polluted PBL in winter, most BC populations lay between $100-200 \mathrm{~nm}$ core diameter and 200$300 \mathrm{~nm}$ coated diameter, in contrast to the diluted PBL with a significant fraction of uncoated $\mathrm{BC}$ and a coated diameter at $100-140 \mathrm{~nm}$. The summer polluted PBL showed a reduced fraction of bare $\mathrm{BC}$ but a range of coating thickness for coated BC. Such analysis in mapping the size-resolved mixing state of a single BC particle on the space of uncoatedcoated size can resolve the optical (contour in Fig. 5f) and hygroscopic (contour in Fig. $5 \mathrm{~g}$ ) properties that $\mathrm{BC}$ particle microphysics could influence, which will be discussed next.

\subsection{Optical properties of $\mathrm{BC}$}

Figures $6 \mathrm{a}$ and $\mathrm{b}$ and S4 in the Supplement show the mass absorption cross section (MAC) of uncoated and coated BC for different PBL types in both seasons. Summer showed systematically higher MAC $\left(7.2 \pm 0.1 \mathrm{~m}^{2} \mathrm{~g}^{-1}\right)$ than winter $\left(6.6 \pm 0.3 \mathrm{~m}^{2} \mathrm{~g}^{-1}\right)$ for uncoated $\mathrm{BC}$, because the $\mathrm{BC}$ core was smaller in summer than winter (Figs. S2 and S3 in the Supplement). The MAC for coated BC was largely modulated by coatings, showing positive correlation with $\mathrm{PM}_{1}$ in winter $\left(\mathrm{MAC}_{\mathrm{BC} \text {,coated }}=0.09 \cdot \mathrm{PM}_{1}+8.7, r=0.79\right)$ and summer $\left(\mathrm{MAC}_{\mathrm{BC} \text {,coated }}=0.12 \cdot \mathrm{PM}_{1}+9.5, r=0.5\right)$, corresponding to the diluted to polluted PBL types. The enhanced absorption efficiency of coated $\mathrm{BC}$ with increased pollution level was consistent with previous studies over this region (Zhang et al., 2018; Ding et al., 2019a). The mean $\mathrm{MAC}_{\mathrm{BC} \text {,coated }}$ for the polluted PBL in summer $\left(11 \pm 1 \mathrm{~m}^{2} \mathrm{~g}^{-1}\right)$ was higher than that in winter $\left(10.7 \pm 0.9 \mathrm{~m}^{2} \mathrm{~g}^{-1}\right)$ by $2 \%$. The neutral and diluted PBL also had a higher MAC in summer than winter (by $8 \%$ and $22 \%$, respectively). The overall higher absorption efficiency of BC in summer (especially in the diluted PBL) was due to the smaller core size, leading to a higher baseline MAC for uncoated BC by $10 \%$ than winter. This effect prevailed over the even lower coating amount and associated absorption enhancement in summer (Fig. 5b). Notably, the $\mathrm{MAC}_{\mathrm{BC}}$ for the diluted summer PBL had been enhanced by both reduced $\mathrm{BC}$ core size and increased coatings (Fig. 5b), reaching an almost equivalent MAC compared to the winter neutral PBL. This means that at the top of the clean PBL in summer there was a BC layer with high absorbing capacity (in contrast to winter with a much lower MAC), which may efficiently absorb the strong solar radiation.

The single-scattering albedo at $\lambda=550 \mathrm{~nm}\left(\mathrm{SSA}_{550}\right)$ in winter was systematically lower for all PBL types (Figs. 6c and $\mathrm{d}$ and $\mathrm{S} 4$ ) by $0.06,0.05$ and 0.08 than summer for the diluted, neutral and polluted PBLs, respectively. The decreased $\mathrm{SSA}_{550}$ was in line with the increased BC mass faction (Fig. 3) and also influenced by the absorbing efficiency, as it was reported that the SSA of elemental carbon (EC) particles was as low as 0.25 (Srivastava et al., 2020). Our winter results here were comparable to previous aircraft measurements over the Beijing region in the cold season of 2016, with SSA ranging from 0.8 to 0.98 from the clean to heavily polluted periods in the PBL (Tian et al., 2020). For the diluted PBL in winter, $\mathrm{SSA}_{550}$ could reach as low as $0.86 \pm 0.02$ when $\mathrm{BC}$ mass fraction reached $7 \% \pm 1.5 \%$ (Fig. 3k). This was within the range of that study in the clean period at SSA $=0.8-0.85$ in the PBL, and the neutral and polluted PBLs were within a similar range in transition and the fully polluted PBL at SSA $=0.85-0.98$, suggesting the clusters here may represent different development stages of pollution events. The lower SSA in the winter PBL than summer tended to induce radiative effects towards a more positive effect (Hansen et al., 1981; Haywood and Ramaswamy, 1998 ) at the top of the PBL, in particular for the clean winter PBL.

\subsection{Hygroscopic properties of $\mathrm{BC}$}

The droplet activation of $\mathrm{BC}$ is determined by the particle size and hygroscopicity, where the coatings play roles in enlarging the entire BC size (Dusek et al., 2006a, b) and increasing its hygroscopicity (Liu et al., 2013). Both factors can be obtained by our observation of size-solved mixing state of BC. The coated BC diameter based on number concentration (coated CMD) is shown in Fig. 7a and b. The CMD of coated BC in the winter polluted PBL was $0.19 \pm 0.05 \mu \mathrm{m}$, which was the largest among PBL types. Generally, the coated BC CMD was in positive correlation with the PM, in winter fitted as $\mathrm{CMD}=0.003 \times \mathrm{PM}_{1}+0.14$ $(r=0.69)$ and in summer as $\mathrm{CMD}=0.001 \times \mathrm{PM}_{1}+0.11$ $(r=0.73)$. The coated BC CMD in winter PBL was larger than summer by 14,35 and $56 \mathrm{~nm}$ for diluted, neutral and polluted PBLs, respectively.

The hygroscopicity parameter of the $\mathrm{BC}$-containing particle $\left(\kappa_{\mathrm{BCc}}\right)$ at the size of the CMD is positively correlated with coating content. In winter $\kappa_{\mathrm{BCc}}$ was at $0.15 \pm 0.02$, $0.20 \pm 0.03$ and $0.24 \pm 0.03$ for the diluted, neutral and polluted PBLs, respectively, while the corresponding val- 

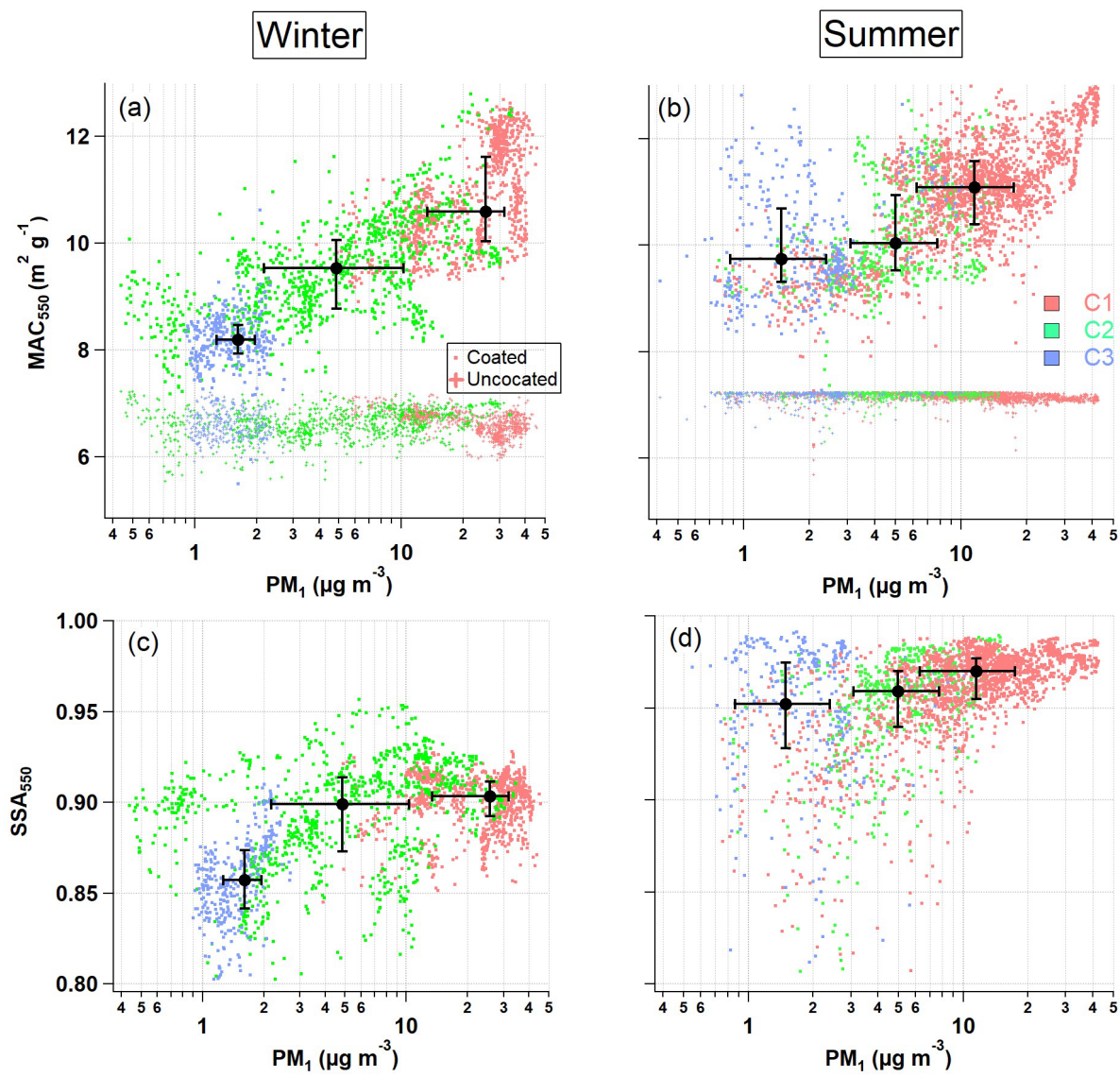

Figure 6. Optical properties of BC for the three PBL types in both seasons. Panels (a) and (b) are the mass absorption cross section at $\lambda=550 \mathrm{~nm}\left(\mathrm{MAC}_{550}\right)$, with dot and plus markers denoting coated and uncoated BC, respectively. Panels (c) and (d) are single-scattering albedo at $\lambda=550 \mathrm{~nm}\left(\mathrm{SSA}_{550}\right)$. In each panel, the solid circles and whiskers denote the median and 25 th and 75 th percentiles, respectively.

ues were $0.19 \pm 0.03,0.20 \pm 0.03$ and $0.22 \pm 0.03$ in summer, consistent with the reduced $D_{\mathrm{p}} / D_{\mathrm{c}}$ from the polluted PBL to the diluted PBL for both seasons. $\kappa_{\mathrm{BCc}}$ could be fitted as $\kappa_{\mathrm{BCc}}=0.003 \times \mathrm{PM}_{1}+0.17(r=0.77)$ and $\kappa_{\mathrm{BCc}}+0.004 \times \mathrm{PM}_{1}+0.17(r=0.49)$ for winter and summer, respectively. Note that the summer-diluted PBL had a significantly higher $\kappa(0.19 \pm 0.03)$ than winter for the same PBL type.

After obtaining the CMD of coated BC and the corresponding $\kappa_{\mathrm{BCc}}$, a critical water superstation (SS) could be derived from the Kölher model (Fig. S5 in the Supplement) for $\mathrm{BC}$ at the size of the CMD to be activated. By assuming that all of the population larger than the CMD could also be consequently activated (because of the larger particle size and higher hygroscopicity), the SS obtained above is thus the lower estimate for half of the number population of $\mathrm{BC}$ to be activated, termed $\mathrm{SS}_{\text {half }}$. In line with the increased coated $\mathrm{BC}$ size and particle hygroscopicity, $\mathrm{SS}_{\text {half }}$ decreased with increased pollution level, from $0.21 \% \pm 0.08 \%$ to $0.1 \% \pm 0.03 \%$ for the winter-diluted to polluted PBL and from $0.22 \% \pm 0.06 \%$ to $0.17 \% \pm 0.05 \%$ for summer. This highlights the lowest possible SS required to activate $\mathrm{BC}$ in the polluted winter PBL, and for the same PBL type, summer will need a higher SS, apart from occasionally some lower $\mathrm{SS}_{\text {half }}$ for the summer-diluted PBL. This potential $\mathrm{CCN}$ ability of $\mathrm{BC}$ is derived from the physical properties of $\mathrm{BC}$ itself, but the actual activation of $\mathrm{BC}$ depends on the ambient superstation condition which is determined by the size distribution of existing droplets and other aerosols competing with CCN (Pruppacher et al., 1998; McFiggans et al., 2006). The results here generally consistent with a previous surface measurement of $\mathrm{BC} C \mathrm{CN}$ activation in urban Nanjing as constrained by size-resolved compositions (Wu et al., 2019) when an activation fraction of $33 \%$ at $\mathrm{SS}=0.1 \%$ was found. A previous study using flight measurements over the NCP region (Ding et al., 2019a) found a $\mathrm{SS}=0.08 \%$ required to activate half of the $\mathrm{BC}$ number in heavy pollution conditions, consistent with the polluted PBL here. 

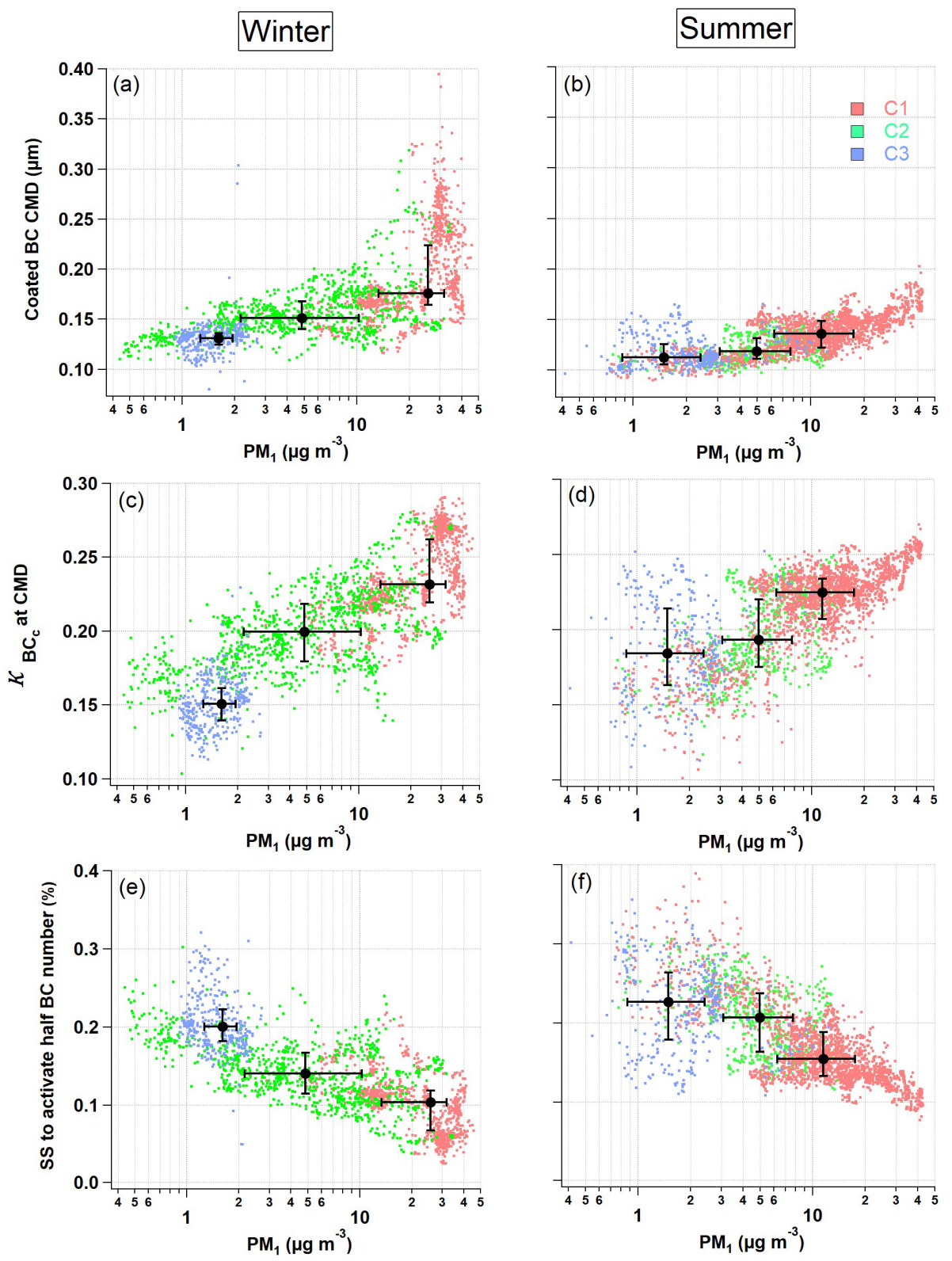

Figure 7. Hygroscopic properties of BC for the three PBL types in both seasons. Panels (a) and (b) are the count median diameter of coated $\mathrm{BC}$; panels (c) and (d) are the $\kappa_{\mathrm{BCc}}$ assuming $\kappa_{\text {coating }}=0.3$; panels (e) and (f) are the supersaturation (SS) to activate half of the BC number population. In each panel, the solid circles and whiskers denote the median and 25 th and 75 th percentiles, respectively.

\section{Conclusions}

By performing continuous measurement on a mountain site located at the top of the planetary boundary layer (PBL) over the North China Plain region in winter and summer, the optical and hygroscopic properties of $\mathrm{BC}$ were investigated. We identified three types of PBLs, all persistently influenced by surface anthropogenic emission on a daily basis through daytime convective mixing, but which could be either enhanced or diluted subject to received air masses. By investigating the detailed microphysical properties of $\mathrm{BC}$, this study pro- vides a clear picture of optical and hygroscopic characteristics of BC at the top of anthropogenically influenced PBL. Highlighted information includes higher $\mathrm{BC}$ mass fractions in winter than summer, corresponding to a lower singlescattering albedo by $0.05-0.08$, especially the lowest for the diluted winter PBL $(0.86 \pm 0.02)$; both mass absorbing efficiency and $\mathrm{CCN}$ ability of $\mathrm{BC}$ are positively correlated with the pollution level of the PBL due to enhanced coating content under a more polluted environment; e.g. from the diluted to polluted PBL, coating content increased by $39 \%(11 \%)$, absorbing efficiency increased by $31 \%(10 \%)$, and the water 
supersaturation in activating half number of $\mathrm{BC}$ decreased by $53 \%(26 \%)$ for winter and summer, respectively. It clearly demonstrates that $\mathrm{BC}$ with higher coating content could be efficiently incorporated into liquid clouds, and meanwhile this BC had a high absorbing capacity, which means this highly absorbing BC may have great potential for in-cloud heating (Jacobson, 2012; Nenes and et al., 2002).

Compared to surface measurement, the results here are more directly linked to the aerosol properties closer to the condensation level which is subsequently $\mathrm{CCN}$-activated. $\mathrm{BC}$ located at this layer more importantly determines its heating impacts due to receiving stronger solar radiation. Rather than being subject to significant scavenging processes of lowlevel emissions, $\mathrm{BC}$ transported to the lower free troposphere may be transported to a wider region (Weinzierl, 2008; Yang et al., 2018; Govardhan et al., 2017), exerting regional direct and indirect radiative impacts.

Data availability. The data in this study are available from the corresponding author upon request (dantongliu@zju.edu.cn).

Supplement. The supplement related to this article is available online at: https://doi.org/10.5194/acp-21-681-2021-supplement.

Author contributions. DL, DZ and DD led and designed the study. SD, DL, DZ, KH, PT, RL, YC, FW, HH and MH set up and conducted the experiment. SD, DL and KH contributed to the data analysis. SD and DL wrote the paper.

Competing interests. The authors declare that they have no conflict of interest.

Acknowledgements. This research was supported by the National Key Research and Development Program of China (2016YFA0602001) and the National Natural Science Foundation of China (41875167). Part of this work is supported by the National Center of Meteorology, Abu Dhabi, UAE, under the UAE Research Program for Rain Enhancement Science.

Financial support. This research has been supported by the National Key Research and Development Program of China (grant no. 2016YFA0602001) and the National Natural Science Foundation of China (grant no. 41875167).

Review statement. This paper was edited by James Allan and reviewed by Atul Kumar Srivastava and one anonymous referee.

\section{References}

Bao, F., Li, M., Zhang, Y., Chen, C., and Zhao, J.: Photochemical Aging of Beijing Urban $\mathrm{PM}_{2.5}$ : $\mathrm{HONO}$ Production, Environ. Sci. Technol., 52, 6309-6316, https://doi.org/10.1021/acs.est.8b00538, 2018.

Bennett, L. J., Weckwerth, T. M., Blyth, A. M., Geerts, B., Miao, Q., and Richardson, Y.: Observations of the Evolution of the Nocturnal and Convective Boundary Layers and the Structure of OpenCelled Convection on 14 June 2002, Mon. Weather Rev., 138 , 2589-2607, 2010.

Bohren, C. F. and Huffman, D. R.: Absorption and Scattering by a Sphere, in: Absorption and Scattering of Light by Small Particles, 82-129, 1998.

Bond, T. C. and Bergstrom, R.: Light Absorption by Carbonaceous Particles: An Investigative Review, Aerosol Sci. Tech., 40, 27 67, 2006

Bond, T. C., Doherty, S. J., Fahey, D. W., Forster, P. M., Berntsen, T., DeAngelo, B. J., Flanner, M. G., Ghan, S., Kärcher, B., Koch, D., Kinne, S., Kondo, Y., Quinn, P. K., Sarofim, M. C., Schultz, M. G., Schulz, M., Venkataraman, C., Zhang, H., Zhang, S., Bellouin, N., Guttikunda, S. K., Hopke, P. K., Jacobson, M. Z., Kaiser, J. W., Klimont, Z., Lohmann, U., Schwarz, J. P., Shindell, D., Storelvmo, T., Warren, S. G., and Zender, C. S.: Bounding the role of black carbon in the climate system: A scientific assessment, J. Geophys. Res.-Atmos., 118, 5380-5552, https://doi.org/10.1002/jgrd.50171, 2013.

Bretherton, C. S. and Wyant, M. C.: Moisture Transport, LowerTropospheric Stability, and Decoupling of Cloud-Topped Boundary Layers, J. Atmos. Sci., 54, 148-167, 1997.

Cheng, Y. F., Su, H., Rose, D., Gunthe, S. S., Berghof, M., Wehner, B., Achtert, P., Nowak, A., Takegawa, N., Kondo, Y., Shiraiwa, M., Gong, Y. G., Shao, M., Hu, M., Zhu, T., Zhang, Y. H., Carmichael, G. R., Wiedensohler, A., Andreae, M. O., and Pöschl, U.: Size-resolved measurement of the mixing state of soot in the megacity Beijing, China: diurnal cycle, aging and parameterization, Atmos. Chem. Phys., 12, 4477-4491, https://doi.org/10.5194/acp-12-4477-2012, 2012.

Chow, J. C., Watson, J. G., Lowenthal, D. H., Antony Chen, L. W., and Motallebi, N.: $\mathrm{PM}_{2.5}$ source profiles for black and organic carbon emission inventories, Atmos. Environ., 45, 5407-5414, https://doi.org/10.1016/j.atmosenv.2011.07.011, 2011.

Chuang, C. C., Penner, J. E., Prospero, J. M., Grant, K. E., Rau, G. H., and Kawamoto, K.: Cloud susceptibility and the first aerosol indirect forcing: Sensitivity to black carbon and aerosol concentrations, J. Geophys. Res., 107, 4564, https://doi.org/10.1029/2000JD000215, 2002.

Chung, C. E., Ramanathan, V., and Kiehl, J. T.: Effects of the south Asian absorbing haze on the northeast monsoon and surface-air heat exchange, J. Climate, 15, 2462-2476, 2002.

Cross, E. S., Slowik, J. G., Davidovits, P., Allan, J. D., Worsnop, D. R., Jayne, J. T., Lewis, D. K., Canagaratna, M., and Onasch, T. B.: Laboratory and ambient particle density determinations using light scattering in conjunction with aerosol mass spectrometry, Aerosol Sci. Technol., 41, 343, 2007.

Ding, A., Huang, X., Nie, W., Sun, J., Kerminen, V. M., Petaja, T., Su, H., Cheng, Y., Yang, X., and Wang, M.: Enhanced haze pollution by black carbon in megacities in China, Geophys. Res. Lett., 43, 2873-2879, 2016. 
Ding, S., Liu, D., Zhao, D., Hu, K., Tian, P., Zhou, W., Huang, M., Yang, Y., Wang, F., and Sheng, J.: Size-Related Physical Properties of Black Carbon in the Lower Atmosphere over Beijing and Europe, Environ. Sci. Technol., 53, 11112-11121, 2019a.

Ding, S., Zhao, D., He, C., Huang, M., He, H., Tian, P., Liu, Q., Bi, K., Yu, C., Pitt, J., Chen, Y., Ma, X., Chen, Y., Jia, X., Kong, S., Wu, J., Hu, D., Hu, K., Ding, D., and Liu, D.: Observed Interactions Between Black Carbon and Hydrometeor During Wet Scavenging in Mixed-Phase Clouds, Geophys. Res. Lett., 46, 84538463, https://doi.org/10.1029/2019gl083171, 2019 b.

Draxler, R. R. and Hess, G.: An overview of the HYSPLIT_4 modelling system for trajectories, Aust. Meteorol. Mag., 47, 295308, 1998

Dusek, U., Frank, G., Hildebrandt, L., Curtius, J., Schneider, J., Walter, S., Chand, D., Drewnick, F., Hings, S. S., and Jung, D.: Size matters more than chemistry for cloud-nucleating ability of aerosol particles, Science, 312, 1375-1378, 2006 a.

Dusek, U., Reischl, G. P., and Hitzenberger, R.: CCN activation of pure and coated carbon black particles, Environ. Sci. Technol., 40, 1223-1230, 2006b.

Gao, R. S., Schwarz, J. P., Kelly, K. K., Fahey, D. W., Watts, L. A., Thompson, T. L., Spackman, J. R., Slowik, J. G., Cross, E. S., and Han, J.: A Novel Method for Estimating Light-Scattering Properties of Soot Aerosols Using a Modified Single-Particle Soot Photometer, Aerosol Sci. Tech., 41, 125-135, 2007.

Govardhan, G., Satheesh, S. K., Nanjundiah, R., Moorthy, K. K., and Babu, S. S.: Possible climatic implications of high-altitude black carbon emissions, Atmos. Chem. Phys., 17, 9623-9644, https://doi.org/10.5194/acp-17-9623-2017, 2017.

Grivas, G., Chaloulakou, A., and Kassomenos, P.: An overview of the $\mathrm{PM}_{10}$ pollution problem, in the Metropolitan Area of Athens, Greece. Assessment of controlling factors and potential impact of long range transport, Sci. Total Environ., 389, 165177, https://doi.org/10.1016/j.scitotenv.2007.08.048, 2008.

Guleria, R. P., Kuniyal, J. C., Dhyani, P. P., Joshi, R. C., and Sharma, N. L.: Impact of aerosol on surface reaching solar irradiance over Mohal in the northwestern Himalaya, India, J. Atmos. Sol.-Terr. Phy., 108, 41-49, 2014.

Hallquist, M., Wenger, J. C., Baltensperger, U., Rudich, Y., Simpson, D., Claeys, M., Dommen, J., Donahue, N. M., George, C., Goldstein, A. H., Hamilton, J. F., Herrmann, H., Hoffmann, T., Iinuma, Y., Jang, M., Jenkin, M. E., Jimenez, J. L., Kiendler-Scharr, A., Maenhaut, W., McFiggans, G., Mentel, Th. F., Monod, A., Prévôt, A. S. H., Seinfeld, J. H., Surratt, J. D., Szmigielski, R., and Wildt, J.: The formation, properties and impact of secondary organic aerosol: current and emerging issues, Atmos. Chem. Phys., 9, 5155-5236, https://doi.org/10.5194/acp9-5155-2009, 2009.

Han, S., Kondo, Y., Oshima, N., Takegawa, N., Miyazaki, Y., Hu, M., Lin, P., Deng, Z. Z., Zhao, Y., and Sugimoto, N.: Temporal variations of elemental carbon in Beijing, J. Geophys. Res., 114, D23202, https://doi.org/10.1029/2009JD012027, 2009.

Hansen, J., Johnson, D. W., Lacis, A. A., Lebedeff, S., Lee, P., Rind, D., and Russell, G. L.: Climate impact of increasing atmospheric carbon dioxide, Science, 213, 957-966, 1981.

Hansen, J., Sato, M., Ruedy, R., Nazarenko, L., Lacis, A., Schmidt, G. A., Russell, G., Aleinov, I., Bauer, M., Bauer, S., Bell, N., Cairns, B., Canuto, V., Chandler, M., Cheng, Y., Del Genio, A., Faluvegi, G., Fleming, E., Friend, A., Hall, T., Jackman, C., Kel- ley, M., Kiang, N., Koch, D., Lean, J., Lerner, J., Lo, K., Menon, S., Miller, R., Minnis, P., Novakov, T., Oinas, V., Perlwitz, J., Perlwitz, J., Rind, D., Romanou, A., Shindell, D., Stone, P., Sun, S., Tausnev, N., Thresher, D., Wielicki, B., Wong, T., Yao, M., and Zhang, S.: Efficacy of climate forcings, J. Geophys. Res.Atmos., 110, https://doi.org/10.1029/2005jd005776, 2005.

Haywood, J. M. and Ramaswamy, V.: Global sensitivity studies of the direct radiative forcing due to anthropogenic sulfate and black carbon aerosols, J. Geophys. Res., 103, 6043-6058, 1998.

Hu, K., Zhao, D., Liu, D., Ding, S., Tian, P., Yu, C., Zhou, W., Huang, M., and Ding, D.: Estimating radiative impacts of black carbon associated with mixing state in the lower atmosphere over the northern North China Plain, Chemosphere, 252, 126455, https://doi.org/10.1016/j.chemosphere.2020.126455, 2020.

Jacobson, M. Z.: Investigating cloud absorption effects: global absorption properties of black carbon, tar balls, and soil dust in clouds and aerosols, J. Geophys. Res.-Atmos., 117, D06205, https://doi.org/10.1029/2011JD017218, 2012.

Ji, D., Yan, Y., Wang, Z., He, J., Liu, B., Sun, Y., Gao, M., Li, Y., Cao, W., Cui, Y., Hu, B., Xin, J., Wang, L., Liu, Z., Tang, G., and Wang, Y.: Two-year continuous measurements of carbonaceous aerosols in urban Beijing, China: Temporal variations, characteristics and source analyses, Chemosphere, 200, 191200, https://doi.org/10.1016/j.chemosphere.2018.02.067, 2018.

Jorba, O., Perez, C., Rocadenbosch, F., and Baldasano, J. M.: Cluster analysis of 4 day back trajectories arriving in the Barcelona Area (Spain) from 1997 to 2002, J. Appl. Meteorol., 43, 887901, 2004.

Koch, D. and Del Genio, A. D.: Black carbon semi-direct effects on cloud cover: review and synthesis, Atmos. Chem. Phys., 10, 7685-7696, https://doi.org/10.5194/acp-10-7685-2010, 2010.

Laborde, M., Crippa, M., Tritscher, T., Jurányi, Z., Decarlo, P. F., Temime-Roussel, B., Marchand, N., Eckhardt, S., Stohl, A., Baltensperger, U., Prévôt, A. S. H., Weingartner, E., and Gysel, M.: Black carbon physical properties and mixing state in the European megacity Paris, Atmos. Chem. Phys., 13, 5831-5856, https://doi.org/10.5194/acp-13-5831-2013, 2013.

Li, M., Zhang, Q., Kurokawa, J.-I., Woo, J.-H., He, K., Lu, Z., Ohara, T., Song, Y., Streets, D. G., Carmichael, G. R., Cheng, Y., Hong, C., Huo, H., Jiang, X., Kang, S., Liu, F., Su, H., and Zheng, B.: MIX: a mosaic Asian anthropogenic emission inventory under the international collaboration framework of the MICS-Asia and HTAP, Atmos. Chem. Phys., 17, 935-963, https://doi.org/10.5194/acp-17-935-2017, 2017.

Liu, D., Flynn, M., Gysel, M., Targino, A., Crawford, I., Bower, K., Choularton, T., Jurányi, Z., Steinbacher, M., Hüglin, C., Curtius, J., Kampus, M., Petzold, A., Weingartner, E., Baltensperger, U., and Coe, H.: Single particle characterization of black carbon aerosols at a tropospheric alpine site in Switzerland, Atmos. Chem. Phys., 10, 7389-7407, https://doi.org/10.5194/acp10-7389-2010, 2010.

Liu, D., Allan, J., Whitehead, J., Young, D., Flynn, M., Coe, H., McFiggans, G., Fleming, Z. L., and Bandy, B.: Ambient black carbon particle hygroscopic properties controlled by mixing state and composition, Atmos. Chem. Phys., 13, 2015-2029, https://doi.org/10.5194/acp-13-2015-2013, 2013.

Liu, D., Allan, J. D., Young, D. E., Coe, H., Beddows, D., Fleming, Z. L., Flynn, M. J., Gallagher, M. W., Harrison, R. M., Lee, J., Prevot, A. S. H., Taylor, J. W., Yin, J., Williams, P. I., and Zot- 
ter, P.: Size distribution, mixing state and source apportionment of black carbon aerosol in London during wintertime, Atmos. Chem. Phys., 14, 10061-10084, https://doi.org/10.5194/acp-1410061-2014, 2014.

Liu, D., Whitehead, J. D., Alfarra, M. R., Reyesvillegas, E., Spracklen, D. V., Reddington, C. L., Kong, S., Williams, P. I., Ting, Y., and Haslett, S. L.: Black-carbon absorption enhancement in the atmosphere determined by particle mixing state, Nat. Geosci., 10, 184-188, 2017.

Liu, D., Joshi, R., Wang, J., Yu, C., Allan, J. D., Coe, H., Flynn, M. J., Xie, C., Lee, J., Squires, F., Kotthaus, S., Grimmond, S., Ge, X., Sun, Y., and Fu, P.: Contrasting physical properties of black carbon in urban Beijing between winter and summer, Atmos. Chem. Phys., 19, 6749-6769, https://doi.org/10.5194/acp19-6749-2019, 2019a.

Liu, D., Zhao, D., Xie, Z., Yu, C., Chen, Y., Tian, P., Ding, S., Hu, K., Lowe, D., and Liu, Q.: Enhanced heating rate of black carbon above the planetary boundary layer over megacities in summertime, Environ. Res. Lett., 14, 124003, https://doi.org/10.1088/1748-9326/ab4872, 2019 b.

Liu, P., Zhao, C., Liu, P., Deng, Z., Huang, M., Ma, X., and Tie, X.: Aircraft study of aerosol vertical distributions over Beijing and their optical properties, Tellus B, 61, 756-767, 2009.

Liu, Y., Yan, C., and Zheng, M.: Source apportionment of black carbon during winter in Beijing, Sci. Total Environ., 618, 531541, https://doi.org/10.1016/j.scitotenv.2017.11.053, 2018.

Liu, Z., Hu, B., Ji, D., Wang, Y., Wang, M., and Wang, Y.: Diurnal and seasonal variation of the $\mathrm{PM}_{2.5}$ apparent particle density in Beijing, China, Atmos. Environ., 120, 328-338, 2015.

Makra, L., Matyasovszky, I., Guba, Z., Karatzas, K., and Anttila, P.: Monitoring the long-range transport effects on urban $\mathrm{PM}_{10}$ levels using 3D clusters of backward trajectories, Atmos. Environ., 45, 2630-2641, https://doi.org/10.1016/j.atmosenv.2011.02.068, 2011.

Markou, M. T. and Kassomenos, P.: Cluster analysis of five years of back trajectories arriving in Athens, Greece, Atmos. Res., 98, 438-457, https://doi.org/10.1016/j.atmosres.2010.08.006, 2010.

Mcfarquhar, G. M. and Wang, H.: Effects of aerosols on trade wind cumuli over the Indian Ocean: Model simulations, Q. J. Roy. Meteor. Soc., 132, 821-843, 2006.

McFiggans, G., Artaxo, P., Baltensperger, U., Coe, H., Facchini, M. C., Feingold, G., Fuzzi, S., Gysel, M., Laaksonen, A., Lohmann, U., Mentel, T. F., Murphy, D. M., O’Dowd, C. D., Snider, J. R., and Weingartner, E.: The effect of physical and chemical aerosol properties on warm cloud droplet activation, Atmos. Chem. Phys., 6, 2593-2649, https://doi.org/10.5194/acp-6-25932006, 2006.

Nair, V. S., Babu, S. S., Moorthy, K. K., Sharma, A. K., Marinoni, A., and Ajai: Black carbon aerosols over the Himalayas: direct and surface albedo forcing, Tellus B, 65, 19738, https://doi.org/10.3402/tellusb.v65i0.19738, 2013.

Nenes, A., Conant, W. C., and Seinfeld, J. H.: Black carbon radiative heating effects on cloud microphysics and implications for the aerosol indirect effect 2. Cloud microphysics, J. Geophys. Res.: Atmos., 107, 4605, https://doi.org/10.1029/2002JD002101, 2002.

Panicker, A. S., Pandithurai, G., Safai, P. D., and Prabha, T. V.: Indirect forcing of black carbon on clouds over northeast India, Q. J. Roy. Meteor. Soc., 142, 2968-2973, https://doi.org/10.1002/qj.2878, 2016.

Philipp, A.: Comparison of principal component and cluster analysis for classifying circulation pattern sequences for the European domain, Theor. Appl. Climatol., 96, 31-41, 2009.

Pringle, K. J., Tost, H., Pozzer, A., Pöschl, U., and Lelieveld, J.: Global distribution of the effective aerosol hygroscopicity parameter for CCN activation, Atmos. Chem. Phys., 10, 52415255, https://doi.org/10.5194/acp-10-5241-2010, 2010.

Pruppacher, H. R., Klett, J. D., and Wang, P. K.: Microphysics of Clouds and Precipitation, Aerosol Sci. Tech., 28, 381-382, https://doi.org/10.1080/02786829808965531, 1998.

Raju, M. P., Safai, P. D., Sonbawne, S. M., Buchunde, P. S., Pandithurai, G., and Dani, K. K.: Black carbon aerosols over a high altitude station, Mahabaleshwar: Radiative forcing and source apportionment, Atmos. Pollut. Res., 11, 1408-1417, https://doi.org/10.1016/j.apr.2020.05.024, 2020.

Ramanathan, V. and Carmichael, G.: Global and regional climate changes due to black carbon, Nat. Geosci., 1, 221-227, https://doi.org/10.1038/ngeo156, 2008.

Ramanathan, V., Chung, C. E., Kim, D., Bettge, T. W., Buja, L., Kiehl, J. T., Washington, W. M., Fu, Q., Sikka, D., and Wild, M.: Atmospheric brown clouds: Impacts on South Asian climate and hydrological cycle, P. Natl. Acad. Sci. USA, 102, 5326-5333, 2005.

Rudich, Y., Sagi, A., and Rosenfeld, D.: Influence of the Kuwait oil fires plume (1991) on the microphysical development of clouds, J. Geophys. Res., 108, https://doi.org/10.1029/2003JD003472, 2003.

Schwarz, J. P., Gao, R. S., Fahey, D. W., Thomson, D. S., Watts, L. A., Wilson, J. C., Reeves, J. M., Darbeheshti, M., Baumgardner, D., and Kok, G. L.: Single-particle measurements of midlatitude black carbon and light-scattering aerosols from the boundary layer to the lower stratosphere, J. Geophys. Res., 111, D16207, https://doi.org/10.1029/2006JD007076, 2006.

Srivastava, A., Ram, K., Pant, P., Hegde, P., and Joshi, H.: Black carbon aerosols over Manora Peak in the Indian Himalayan foothills: implications for climate forcing, Environ. Res. Lett., 7, 014002, https://doi.org/10.1088/1748-9326/7/1/014002, 2012a.

Srivastava, A. K., Singh, S., Pant, P., and Dumka, U. C.: Characteristics of black carbon over Delhi and Manora Peak-a comparative study, Atmos. Sci. Lett., 13, 223-230, https://doi.org/10.1002/asl.386, 2012b.

Srivastava, A. K., Mehrotra, B. J., Singh, A., Singh, V., Bisht, D. S., Tiwari, S., and Srivastava, M. K.: Implications of different aerosol species to direct radiative forcing and atmospheric heating rate, Atmos. Environ., 241, 117820, https://doi.org/10.1016/j.atmosenv.2020.117820, 2020.

Srivastava, P., Dey, S., Srivastava, A. K., Singh, S., and Tiwari, S.: Most probable mixing state of aerosols in Delhi NCR, northern India, Atmos. Res., 200, 88-96, https://doi.org/10.1016/j.atmosres.2017.09.018, 2018.

Stokes, R. H. and Robinson, R. A.: Interactions in Aqueous Nonelectrolyte Solutions. I. Solute-Solvent Equilibria, J. Phys. Chem., 70, 2126-2131, 1966.

Sullivan, P. P., Moeng, C., Stevens, B., Lenschow, D. H., and Mayor, S. D.: Structure of the Entrainment Zone Capping the Convective Atmospheric Boundary Layer, J. Atmos. Sci., 55, 3042-3064, 1998. 
Taylor, J. W., Allan, J. D., Liu, D., Flynn, M., Weber, R., Zhang, X., Lefer, B. L., Grossberg, N., Flynn, J., and Coe, H.: Assessment of the sensitivity of core/shell parameters derived using the singleparticle soot photometer to density and refractive index, Atmos. Meas. Tech., 8, 1701-1718, https://doi.org/10.5194/amt-8-17012015, 2015.

Tian, P., Liu, D., Zhao, D., Yu, C., Liu, Q., Huang, M., Deng, Z., Ran, L., Wu, Y., Ding, S., Hu, K., Zhao, G., Zhao, C., and Ding, D.: In situ vertical characteristics of optical properties and heating rates of aerosol over Beijing, Atmos. Chem. Phys., 20, 26032622, https://doi.org/10.5194/acp-20-2603-2020, 2020.

Volkamer, R., Jimenez, J. L., Martini, F. S., Dzepina, K., Zhang, Q., Salcedo, D., Molina, L. T., Worsnop, D. R., and Molina, M. J.: Secondary organic aerosol formation from anthropogenic air pollution: Rapid and higher than expected, Geophys. Res. Lett., 33, L17811, https://doi.org/10.1029/2006GL026899, 2006.

Weinzierl, B.: Radiatively-driven processes in forest fire and desert dust plumes, Forschungsberichte, DLR Deutsches Zentrum fur Luft- und Raumfahrt e.V., Germany, 2008.

Wood, R. and Bretherton, C. S.: Boundary Layer Depth, Entrainment, and Decoupling in the Cloud-Capped Subtropical and Tropical Marine Boundary Layer, J. Climate, 17, 3576-3588, 2004.

Wu, Y., Liu, D., Wang, J., Shen, F., Chen, Y., Cui, S., Ge, S., Wu, Y., Chen, M., and Ge, X.: Characterization of SizeResolved Hygroscopicity of Black Carbon-Containing Particle in Urban Environment, Environ. Sci. Technol., 53, 14212-14221, https://doi.org/10.1021/acs.est.9b05546, 2019.
Xu, W., Han, T., Du, W., Wang, Q., Chen, C., Zhao, J., Zhang, Y., Li, J., Fu, P., Wang, Z., Worsnop, D. R., and Sun, Y: : Effects of Aqueous-Phase and Photochemical Processing on Secondary Organic Aerosol Formation and Evolution in Beijing, China, Environ. Sci. Technol., 51, 762-770, https://doi.org/10.1021/acs.est.6b04498, 2017.

Yang, X., Xu, J., Bi, F., Zhang, Z., Chen, Y., He, Y., Han, F., Zhi, G., Liu, S., and Meng, F.: Aircraft measurement over the Gulf of Tonkin capturing aloft transport of biomass burning, Atmos. Environ., 182, 41-50, https://doi.org/10.1016/j.atmosenv.2018.03.020, 2018.

Zhang, Y., Zhang, Q., Cheng, Y., Su, H., Li, H., Li, M., Zhang, X., Ding, A., and He, K.: Amplification of light absorption of black carbon associated with air pollution, Atmos. Chem. Phys., 18, 9879-9896, https://doi.org/10.5194/acp-18-9879-2018, 2018.

Zhao, D., Huang, M., Tian, P., He, H., Lowe, D., Zhou, W., Sheng, J., Wang, F., Bi, K., Kong, S., Yang, Y., Liu, Q., Liu, D., and Ding, D.: Vertical characteristics of black carbon physical properties over Beijing region in warm and cold seasons, Atmos. Environ., 213, 296-310, https://doi.org/10.1016/j.atmosenv.2019.06.007, 2019. 